\title{
A CASE STUDY OF LYMPHOCYSTIS VIRUS DISEASE IN FARMED GIANT SNAKEHEAD (Channa striata) IN MANDIANGIN, SOUTH KALIMANTAN
}

\author{
Bambang Setyo Sihananto*\#, Hessy Novita*), Christina Wianty*), and Angela Mariana Lusiastuti* \\ *) Mandiangin Freshwater Aquaculture Development Center (MFADC) South Kalimantan \\ Jl. Tahura Sultan Adam Km 14, Mandiangin Barat, Karang Intan, Cempaka, Banjar, Kalimantan Selatan 70661 \\ *) Institute for Freshwater Aquaculture and Fisheries Extension \\ Jl. Sempur No. 1, Bogor 16129
}

(Received 2 April 2018; Final revised 21 March 2019; Accepted 1 April 2019)

\begin{abstract}
Lymphocystis virus has been implicated as the cause of severe infection, mortality, and economic loss in farmed giant snakehead (Channa striata) or gabus fish in Mandiangin South Kalimantan. In Kalimantan, the fish is locally known as Haruan fish and considered to have health-related benefits to human due to its high albumin content. This study aimed to determine the LCDV in gabus fish through histopathological and PCR investigation. Infected LCDV fish have a cluster of warts growths in the skin or fin of a walleye. Infected fishes with an average of total length of $15 \mathrm{~cm}$ and weight of $150 \mathrm{~g}$ were collected from local net cages and earthen ponds. They were transferred into a laboratory, anesthetized, and then subsequently killed by organ dissection. The infected fish tumors were aseptically cut out for histological study and PCR detection. Primer used was forward GII F: 5 'TGG GAT TCC AAY GGT CAA TTA-3' with target band of 468 bp (for genotype-Ili LCDV) and primer reverse R: 5'TTA GAT TAT TGG GCA GCG TT-3' with target band of $250 \mathrm{bp}$ (for genotype-II LCDV) and GIII F: 5' AGG AAA TAA CCG CAG TA GAA TGCA. Lymphocytosis in infected fish showed multifocal to diffuse white, round, firm, papilloma or tumor-like nodules on the skin of the body, fins, eyes, and mouth. The hypertrophied cell was surrounded by a thick smooth hyaline capsule. Stress condition caused by high population density, nutrition deficiencies, decreased dissolved oxygen, suboptimal water quality, and handling may increase the appearance of LCDV symptoms. The result of the present study revealed that histopathology and PCR could be used to diagnose LCDV infection.
\end{abstract}

\section{KEYWORDS: gabus; South Kalimantan; lymphocystis; histopathology; PCR}

\section{INTRODUCTION}

Gabus is a native Indonesian fish. They live in the waters, swamp, reservoirs, and in the rivers where the water is calm. The fish is known by many names locally due to its wide distribution in the Indonesian region. Its scientific name is Channa striata Bloch, 1793 despite some others have called it as Ophiocephalus striatus. The fish's common name is giant snakehead. In Kalimantan, local communities called it haruan fish which is considered to have health benefits due to its high protein content, especially albumin which is good for wound healing process and postpartum recovery (Asikin $\&$ Kusumaningrum, 2018). Gabus can survive in culture conditions ranging from high acidity to near-zero dissolved oxygen.

\footnotetext{
* Correspondence: Freshwater Aquaculture Development Center. Jl. Tahura Sultan Adam Km 14, Mandiangin Barat, Karang Intan, Cempaka, Banjar, Kalimantan Selatan 70661, Indonesia. Tel. + 628115004658

E-mail: bambang.dvm@gmail.com
}

Unfortunately, gabus population in the wild has been declining. The Banjar people (the local people in Kalimantan) depend on wild seed to culture the fish. The Mandiangin Freshwater Aquaculture (BPBAT) has been developing the breeding and mass-production methods of the fish. The methods have been adopted by fish farmers, and currently most of fish farmers no longer depend on wild seed for fish grow out. The Freshwater Aquaculture Development Center (BPBAT) Mandiangin has adopted the name of gabus Haruan for the improved bred fish and acquired the permission to release the fish to be mass cultured (The Document of "Release of Gabus Channa striata Bloch 1793" in October 2014). It was hoped that the released fish has better performance than the Gabus existed in nature and its cultivation technology can be adopted by more fish farmers.

Recently, some fish farms in Mandiangin have suffered disease outbreaks caused by a pathogen agent with a clinical sign as tumor-like in the skin near eye 
and fins of farmed fish. The infection has also caused displeasing fish physical appearance causing unsaleable fish if harvested. This clinical sign has been known as the evidence of infection by lymphocystis disease virus (LCDV). Lymphocystis disease virus (LCDV) is an icosahedral symmetry virus, with size approximately 200-300 nm in diameter and usually appears as a cluster of white or cream-colored warts or flashy growths erupting from the skin or fin of a walleye (Kitamura et al., 2006). Usually, LCDV infections to the external body parts or skin, and internal organ infection were quite rare (Alonso et al., 2005; Cano et al., 2006). Lymphocystis virus has been implicated as the cause of severe disease, mortality, and economic loss in farmed fish and ornamental fish in the wild as well as in hatcheries. Kitamura et al. (2006) stated that the first iridovirus disease described in fish was lymphocystis disease virus (LCDV) which is commonly found in freshwater and marine fish species.

The distribution of LCDV has been reported worldwide such as in Spain, France, Korea, Japan, and China (Le Deuff \& Renault, 1993; Alonso et al., 2005; Shang $\&$ Zhan, 2006; Hossain et al., 2008). Mosharrof \& Myung-J0o (2011) explained that the virus is released into the water when the warts of infected fish rupture. The virus can infect healthy walleye by entering skin abrasions or cuts and then attacking cells in the connection tissue (Mosharrof \& MyungJ00, 2011); and this repeated cycle may futher contaminate culture environment (Fautin \& Allen, 1997). Stress condition caused by high population density, nutrition deficiencies, decreased dissolved oxygen, suboptimal water quality, and handling may increase the occurrences of LCDV (Alonso et al., 2005; Cano et al., 2006). Cano et al. (2006) also reported that Artemia sp. might act as a reservoir host of this disease. The diagnosis of LCDV has been mainly based on the observation of symptoms. To control the distribution of the disease, it is important to know the viral dynamics and ecological niches as well as host fish. Therefore, the present research was to study the LCDV in gabus (Channa striata) through histopathological and PCR investigation.

\section{MATERIALS AND METHODS}

\section{Fish Samples}

LCDV infected fishes were collected from net cages located in Banjarmasin South Kalimantan Province, earth ponds located in Jejangkit village, Barito Kuala District and Keliling Benteng Village Banjar District, and tarpaulin ponds in Mandiangin Village, Banjar District, South Kalimantan with an average total length of $15 \mathrm{~cm}$ and weight of $150 \mathrm{~g}$. They were transferred live into the laboratory of Fish Health Mandiangin
Freshwater Aquaculture Development Center (MFADC), South Kalimantan. The live fishes were anesthetized and subsequently killed by organ dissection according to Ministry of Marine Affairs and Fisheries regulation August 2019 concerning Aquatic Animal Welfare Management. The infected fish showing clinical signs of white warts like tumors were aseptically dissected for histological study and PCR detection.

\section{Sample Preparation for Histological Study}

All fish samples were examined for gross pathology indicators including location, distribution, shape, size, color, consistency, and special features of typical external lesions using the following method. Lymphocystis tumor tissues were fixed with $10 \%$ buffered formalin solution for hematoxylin and eosin staining and later fixed in $2.5 \%$ glutaraldehyde in phosphate buffer saline (0.1 mol/L 1-1, pH 7.4) for 2 hours at $4^{\circ} \mathrm{C}$ for ultra-thin section. Then tissues were postfixed in $1 \% 0$ smium tetroxide in phosphate buffer saline for 1 hour at $4^{\circ} \mathrm{C}$. After fixation, the samples were dehydrated in ascending ethyl alcohol grade series followed by infiltration and embedded in post-fixed Epon-812 epoxy resin according to modification the standard procedures of Musharof \& Myung Ho (2011). The section samples were stained with $1 \%$ toluidine and methylene blue and observed under ultra-microscopy (Musharof \& Myung Ho, 2011).

\section{DNA Extraction}

The tissue of fish tumor that had been fixed with $90 \%$ ethanol was taken 25 to $50 \mathrm{mg}$ and put into a 1.5 $\mathrm{mL}$ microtube and mixed with $500 \mu \mathrm{L}$ DNAzol. The mixture was then crushed using a pestle, then centrifuged at $12,000 \mathrm{rpm}$ for 10 minutes at room temperature. After centrifugation, $400 \mu \mathrm{L}$ of the sample was transferred into a new microtube and added with $0.5 \mathrm{~mL}$ of $100 \%$ alcohol and flipped for 3-6 times then incubated for 1-3 minutes at room temperature. Afterward, the sample was centrifuged at $8,000 \mathrm{rpm}$ for three minutes at room temperature, and the supernatant was discarded. The DNA pellets were washed with $500 \mu \mathrm{L}$ of $95 \%$ alcohol, put into microtubes and flipped 3-6 times, then centrifuged at 8,000 rpm for five minutes at room temperature. This washing process was done two times after which the ethanol was removed, and the DNA pellet was dried. The dried DNA was dissolved in 100-200 $\mu \mathrm{L}$ $\mathrm{ddH} 2 \mathrm{O}$. The DNA solution could be directly used or stored in a freezer $\left(-20^{\circ} \mathrm{C}\right)$ (Kitamura et al., 2006).

\section{PCR Procedure}

According to Kitamura et al. (2006), the fish DNA can be detected using the following composition: PCR mastermix Cocktail Go Green Taq (Promega) $12.5 \mu \mathrm{L}$, 


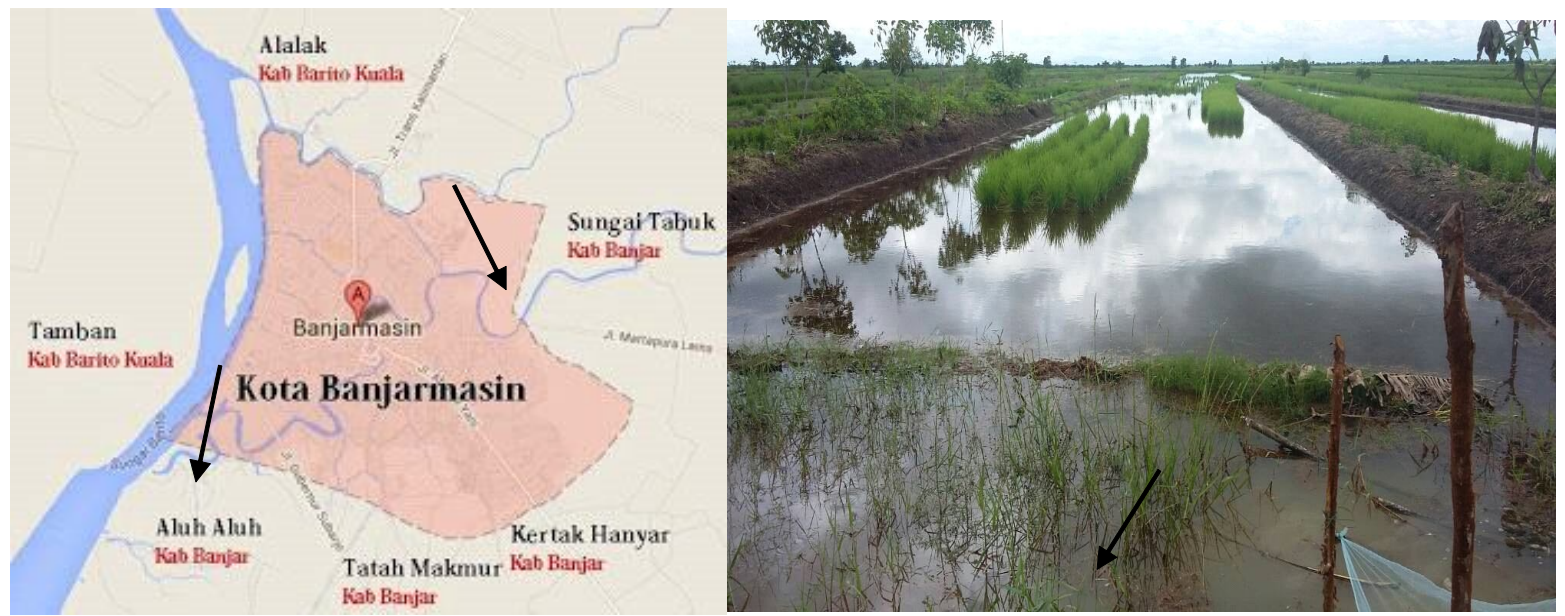

Figure 1. Location of fish samples collection for LCDV study.

nuclease free water $8.5 \mu \mathrm{L}$, primary and reverse primer $1 \mu \mathrm{L}$ and $2 \mu \mathrm{L}$ of fish tumor DNA, respectively. Primer used was forward GII F: 5 'TGG GAT TCC AAY GGT CAA TTA-3' with target band of 468 bp (for genotype-IIi LCDV) and primer reverse R: 5'TTA GAT TAT TGG GCA GCG TT-3' with target band of 250 bp (for genotype-II LCDV) and GIII F: 5' AGG AAA TAA CCG CAG TA GAA TGCA using PCR cycle as follows: for 30 cycles with denaturation $95^{\circ} \mathrm{C}$ for one minute, after that annealing $55^{\circ} \mathrm{C}$ for one minute, and elongation $72{ }^{\circ} \mathrm{C}$ for one minute. The PCR envelope was then run on the $1.5 \%$ gel and then documented with geldoc to get the PCR bands using the 100 bp marker.

\section{Hematological Test}

Blood samples of five LCDV infected fish were collected from the fish caudal vein using $1 \mathrm{~mL}$ syringe containing EDTA as an anticoagulant. Volumes of the blood ranged from 0.5 to $1 \mathrm{~mL}$. The measured parameters in haematological test were total of white and red blood cells, haemoglobine, haematocrit, mean corpuscle volume, mean corpuscle haemoglobin concentration, platelet, and total lymphocytes.

\section{Data Analysis}

All the data histology (macroscopic and microscopic observation), PCR detection, and hematology (white and red blood cells, haemoglobine, haematocrit, mean corpuscle volume, mean corpuscle haemoglobine concentration, platelets, and total lymphocytes) were presented in figures and tables and analyzed descriptively.

\section{RESULT AND DISCUSSIONS}

\section{Macroscopic Observations}

The clinical signs of LCDV showed in Figure 2. Fish with lymphocystis developed macroscopic nodules (0.3-2.0 $\mathrm{mm}$ or more in diameter) that occured primarily on the body surface. The nodules appeared cream-colored to pink or gray.

Mosharrof \& Myung-J0o (2006) argued that water contamination, decreased dissolved oxygen and suboptimal water quality, as well as stress condition from high population density and nutrition deficiencies, may act as predisposition factors to spread the virus.

LCDV is an opportunity pathogen. When fish undergo stress or injured, the LCDV can easily infect the fish. Stress will reduce fish immune system making it easier for fish to be infected by LCDV. The virus can also infect healthy fish walleye by entering the skin abrasions or cuts and then attacking cells in the connecting tissue. Cano et al. (2006) reported that Artemia sp. might act as a carrier host for this disease. In grow-out farming, LCDV was infected cultured fish and then released into water and spread to other fish.

LCDV showed multifocal of papilloma or tumorlike nodules. The color was diffuse white, round, firm, on the skin of the body, fins, eyes, and mouth (Figure 3). The diameter of nodules ranged from 1 to $2 \mathrm{~mm}$. The tumor surrounded the head and neck causing displeasing appearance.

\section{Histological Observations}

Many clusters of lymphocystis cells were obtained in the connecting tissues of the epidermis in fins and skin. The lymphocystis hypertrophied cell was surrounded by a thick smooth hyaline capsule (Figure 4). The nucleus of lymphocystis cell was enlarged, irregular, and contained basophilic marginated chromatin.

According to Hossain et al. (2009), LCDV consisted of two groups of virus: marine and freshwater isolates differentiated by their virus protein profiles. 

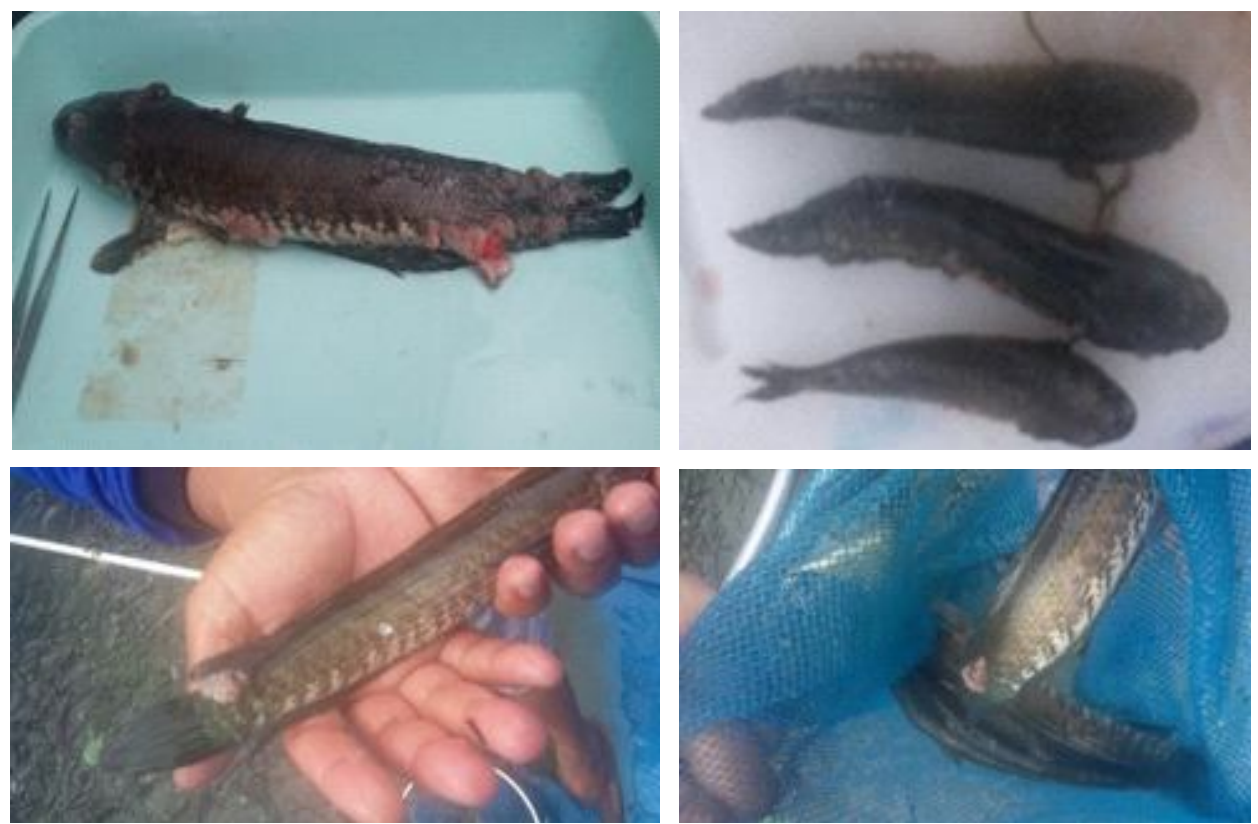

Figure 2. The clinical signs of gabus Haruan infected by LCDV.

However, skin or fin biopsies in histopathology test provided a definitive diagnosis of the type of lymphocystis tumor cells which can be easily differentiated by gross pathology. Valverde et al. (2017) found that the lymphocystis cells was clusters of typical hypertrophied fibroblasts (lymphocysts). They also found dark inclusions within the cytoplasm and enclosed by a hyaline capsule, and were observed in the dermis of fin and skin where they were surrounded by an abundance of infammatory epithelioid that the inclusion body and hyaline capsules were predominant (Valverde et al. 2017). Pirarat et al. (2011) explained that the LCDV was detectable not only in the skeletal muscle and gills lamellae but also in visceral organs such as spleen. Moreover, Pirarat et al. (2011) stated that the senile lymphocystis disease cells became irregular and broken hyaline capsule; their nu- clei disappeared, and cytoplasms were released partly or totally. The present study confirmed that this was the main reason for the spreading of LCDV disease to other fishes during culture in ponds.

The present study showed the presence of LCDV in skin, fin, and near the eye. The cytoplasm of lymphocystis cells was changed, developing basophilic and intracytoplasmic inclusion bodies that appeared as dense vacuolated bodies. In addition, a thick hyaline capsule surrounding the hypertrophied fibroblast was observed in the cytoplasm, especially in the mature lymphocystis cells which are similar to the findings of Valverde et al. (2017). To the best of our knowledge, this was the first time that LCDV was observed in gabus Haruan. Pirarat et al. (2011) found that LCDV affected visceral organs including spleen,
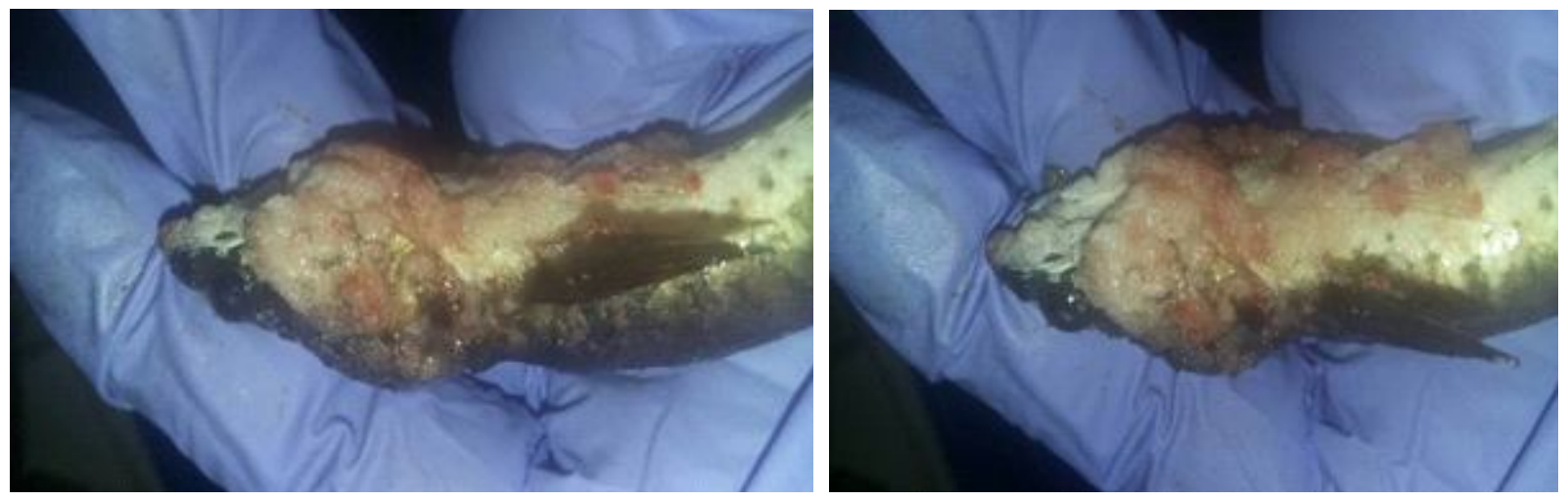

Figure 3. Hypertrophied cells and abnormal growth of normal tissue in the outer skin and near the eye of gabus. White color nodules (tumor) can easily be detected by naked eyes. 

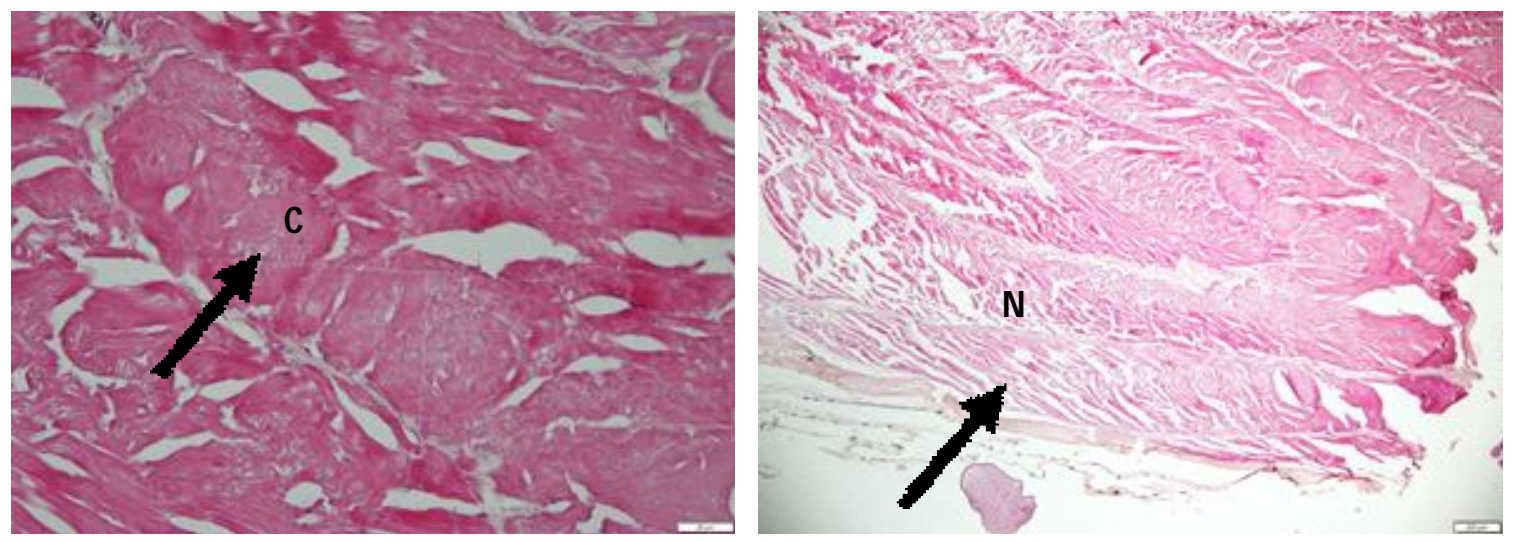

Figure 4. Histopathology of lymphocystis disease characterized by cytomegaly of dermal fibroblasts cells which depending on fish condition and the degree of vascularity of the lesion; C: cytomegaly; N: normal tissue.

head, and kidney trunk. In this present study, different infection was observed where LCDV affected mouth, skeletal muscle, and gills lamellae while visceral organs were not affected. Mosharrof \& Myung-Joo (2006) observed the ultra-microtome photographs of LCDV which showed about $250 \mathrm{~nm}$ in diameter within the peri-nuclear cisterna and membrane-enveloped inclusions scattered in the cytoplasm but not in the nucleus. Table 1 and Table 2 showed hematological result from healthy and infected fishes.

Leucocyte from all LCDV infected fish showed above limit detection (ALD) with very high values except fish labeled as code-2. This means that the fish has leucocytes level above the normal standard. This also gives a strong indication that the fish suffered an infection from the virus. Red blood cell counts were lower compared to the control. The reduced red blood cells may be caused by anemia or abnormalities of new red blood cell formation due to reduced fish immune system.

\section{PCR}

PCR is a rapid, sensitive, and highly specific detection method for fish viruses, which can be a powerful tool to detect iridovirus infections ( $M$ ao et al., 1996). The PCR results suggested that the samples were positive for LCDV (target PCR 250 bp). But, according to Kitamura et al. (2006) when LCDV produced bands at $250 \mathrm{bp}$, it means that the virus grouped into genotype-II. From this research result, we used also GIII forward primer, and the PCR result using this primer was negative. It is highly possible that the isolates from Kalimantan might be a different species of LCDV which should be investigated further in the future.

Kitamura et al. (2005) said the existence of three genotypes in the genus Lymphocysti virus based on the MCP gene nucleotide sequence identity such as genotype-I for LCDV 1, genotype-II for LCDV C and other Japanese flounder isolates, and genotype-III for rockfish isolates (LCDV RF). PCR products obtained

Table 1. Hematological of infected LCDV fish

\begin{tabular}{|c|c|c|c|c|c|c|c|c|c|c|c|}
\hline \multirow[b]{2}{*}{ Code } & \multicolumn{11}{|c|}{ LCDV Hematological test result } \\
\hline & $\begin{array}{c}\text { WBC } \\
\left(\times 10^{3} / \mu \mathrm{L}\right)\end{array}$ & $\begin{array}{c}\text { RBC } \\
\left(\times 10^{6} / \mu \mathrm{L}\right)\end{array}$ & $\begin{array}{l}\text { HGB } \\
(\mathrm{g} / \mathrm{dL})\end{array}$ & $\begin{array}{c}\text { HCT } \\
(\%)\end{array}$ & $\begin{array}{l}\text { MCV } \\
\text { (F) }\end{array}$ & $\begin{array}{r}\mathrm{MCH} \\
(\mathrm{pg})\end{array}$ & $\begin{array}{r}\text { MCHC } \\
(\mathrm{g} / \mathrm{dL})\end{array}$ & $\begin{array}{c}\text { PLT } \\
\left(\times 10^{3} / \mu \mathrm{L}\right)\end{array}$ & $\begin{array}{c}\text { LYM } \\
\left.\text { (x } 10^{3} / \mu \mathrm{L}\right)\end{array}$ & $\begin{array}{c}\text { MXD } \\
\left(\times 10^{3} / \mu \mathrm{L}\right)\end{array}$ & $\begin{array}{c}\text { NEUT } \\
\left(\times 10^{3} / \mu \mathrm{L}\right)\end{array}$ \\
\hline 1 & ALD & 2.95 & 11.6 & 28.7 & 97.3 & 39.3 & 40.4 & 40 & ALD & - & - \\
\hline 2 & 259 & 2.33 & 10.4 & 21.5 & 92.3 & 44.6 & 48.4 & 23 & 249.8 & - & - \\
\hline 3 & ALD & 2.76 & 11.3 & 28.4 & 102.9 & 40.9 & 39.8 & 20 & ALD & - & - \\
\hline 4 & ALD & 3.2 & 11.5 & 33 & 103.1 & 35.9 & 34.8 & 4 & ALD & - & - \\
\hline 5 & ALD & 2.74 & 11.1 & 27.8 & 101.5 & 40.5 & 39.9 & 18 & ALD & - & - \\
\hline C & $>259$ & 8.62 & 5.36 & 21.26 & 149.5 & 37.98 & 25.45 & 0.475 & $>249.8$ & & \\
\hline
\end{tabular}

Note: (-): not detected; (ALD): above limit detection 
Table 2. Hematological of healthy fish

\begin{tabular}{|c|c|c|c|c|c|c|c|c|c|c|c|}
\hline \multirow[b]{2}{*}{ Code } & \multicolumn{11}{|c|}{ Normal hematological test } \\
\hline & $\begin{array}{c}\text { WBC } \\
\left(\times 10^{3} / \mu \mathrm{L}\right)\end{array}$ & $\begin{array}{c}\text { RBC } \\
\left(\times 10^{6} / \mu \mathrm{L}\right)\end{array}$ & $\begin{array}{l}\text { HGB } \\
(g / d L)\end{array}$ & $\begin{array}{l}\text { HCT } \\
(\%)\end{array}$ & $\begin{array}{l}\text { MCV } \\
\text { (F) }\end{array}$ & $\begin{array}{r}\mathrm{MCH} \\
(\mathrm{pg})\end{array}$ & $\begin{array}{r}\text { MCHC } \\
(\mathrm{g} / \mathrm{dL} \text { ) }\end{array}$ & $\begin{array}{c}\text { PLT } \\
\left(\times 10^{3} / \mu \mathrm{L}\right)\end{array}$ & $\begin{array}{c}\text { LYM } \\
\left(\times 10^{3} / \mu \mathrm{L}\right)\end{array}$ & $\begin{array}{c}\text { MXD } \\
\left(\times 10^{3} / \mu \mathrm{L}\right)\end{array}$ & $\begin{array}{c}\text { NEUT } \\
\left(\times 10^{3} / \mu \mathrm{L}\right)\end{array}$ \\
\hline 1 & 228.6 & 1.55 & 5.40 & 24.9 & 160.6 & 34.8 & 21.7 & 0.18 & 96.5 & - & - \\
\hline 2 & 157.7 & 0.87 & 3.80 & 13.5 & 155.2 & 43.7 & 28.1 & 0.94 & 80.4 & - & - \\
\hline 3 & 201.7 & 1.57 & 6.1 & 22.5 & 143.3 & 38.9 & 27.1 & 0.43 & 89.3 & . & - \\
\hline 4 & 214 & 1.66 & 5.7 & 23.1 & 139.2 & 34.3 & 24.7 & 0.40 & 88.4 & - & - \\
\hline 5 & 170.7 & 1.04 & 4.1 & 16.4 & 157.7 & 39.4 & 25 & 0.39 & 89 & - & - \\
\hline 6 & 249.6 & 1.93 & 7.1 & 27.2 & 140.9 & 36.8 & 26.1 & 0.51 & 96.2 & - & - \\
\hline
\end{tabular}

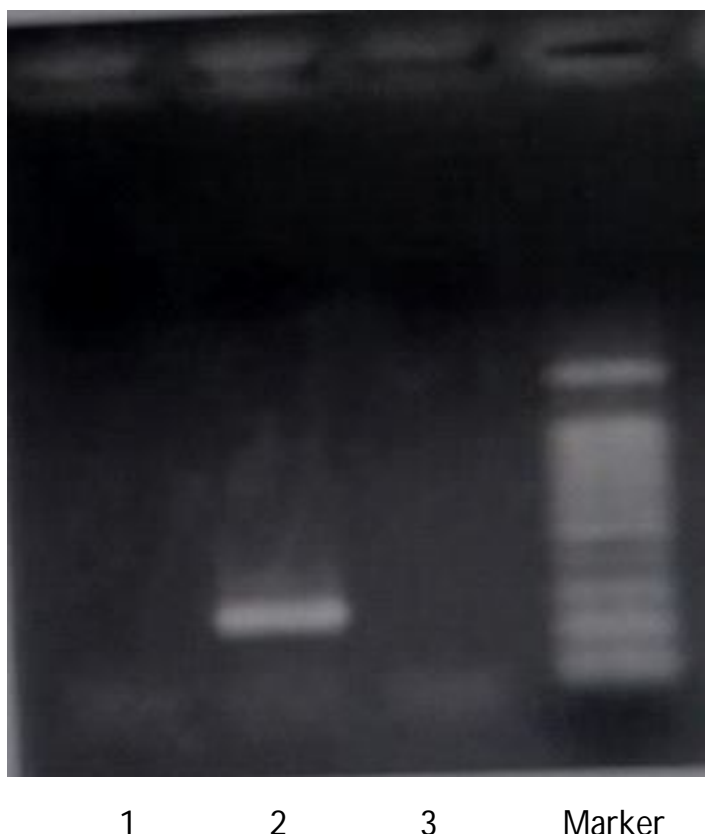

$250 \mathrm{bp}$

Figure 5. LCDV PCR detection with band target $250 \mathrm{bp} ; 1$ ) sample 1; 2) sample 2; 3) negative control; 4) marker $100 \mathrm{bp}$.

using viral DNA from southern European isolates ( 270 bp), was 36 bp smaller than those obtained from the northern European isolates (306 bp) (Kitamura et al., 2005). Zhang et al. (2004) suggested that the isolates from south of Europe might constitute a different species of LCDV. As LCDV has been reported in more than 100 different marine and freshwater fish species, it is obvious that the differences regarding the viral genome structure, gene organization and DNA sequence depend on the host fish or the geographical location (Kitamura et al., 2005). Currently, several molecular techniques have been performed and compared for detection of LCDV, for example, LCDV propagation in cells. This method has successfully allowed LDCV detection using methods such as PCR, immunoblot or cyto metry (Cano et al., 2006; Iwamoto et al., 2002; and Qin et al., 2006).

\section{CONCLUSION}

This current study has shown that LDCV can be diagnosed using histopathology and PCR methods. Signs of LDCV infection is apparent on the mouth, skeletal muscle, and gills lamellae but did not reach the visceral organs. Haematological profiles of fish also give strong indication of LDCV infection through high level of leucocyte and decrased level of red blood counts. The PCR has produced a positive result regarding LDCV infection which give storng indication of a different species of LDCV. In conclusion, this current study suggest that histopathology, PCR, and 
haematology tests are sufficient to detect lymphocystis disease. Future development of LDCV detection methods has to be directed toward developing sensitive, rapid, and economically feasible detection method that can directly be used under field conditions.

\section{ACKNOWLEDGMENTS}

We thank the Head of Mandiangin Freshwater Aquaculture Development Center (MFADC) for providing access and use of facilities at the Histology and Wet Laboratories. We also thank the Research Institute for Freshwater Aquaculture and Fisheries Extension for their help in virus diagnosis.

\section{REFERENCES}

Alonso, M.C., Cano, I., Garcia-Rosado, E., Castro, D., Lamas, J., \& Barja, J.L. (2005). Isolation of lymphocystis disease virus (LCDV) from sole (Solease negalensis) and black spot sea bream (Pagellus bogaraveo). Journal of Fish Disease, 28, 221228.

Asikin, A.N. \& Kusumaningrum, I. (2018). Albumin profile of snakehead fish (Channa striata) from East Kalimantan, Indonesia. 1st International Conference on Tropical Studies and Its Application (ICTROPS). IOP Publishing, IOP Conf. Series: Earth and Environmental Science 144(2018) 012035; DOI: 10.1088/ 1755-1315/144/1/012035.

Cano, I., Alonso, M.C., Garcia-Rosado, E., Saint-Jean S.R., Castro, D., \& Borrego, J.J. (2006). Detection of lymphocystis disease virus (LCDV) in asymptomatic cultured gilt-head seabream (Sparus aurata L.) using an immunoblot technique. Veterinary Microbiology, 113, 137-141.

Fautin, D.G. \& Allen, G.R. (1997). Anemone fishes and their host sea anemones. Minneapolis, USA: Voyageur Press, $160 \mathrm{pp}$.

Hossain, M., Song, J.Y., Kitamura, S.I., Jung, S.J., \& Oh, M.J. (2009). Phylogenetic analysis of lymphocystis disease virus from tropical ornamental fish species based on a major capsid protein gene. Journal of Fish Disease, 31, 473-479.
Iwamoto, R., Hasegawa, O., LaPatra, S.E., \& Yosumizu, M. (2002). Isolation and characterization of the Japanese flounder (Paralichthys olivaceus) lymphocystis disease virus. Journal of Aquatic Animal Health, 14, 114-123.

Kitamura, S.I., Jung, S.J., Kim, W.S., Nishizwa, T., Yoshimizu, M., and Oh, M.J. (2006). A new genotype lymphocystis, LCDV-RF, from lymphocytes diseased rockfish. Archives of Virology, 151(3), 607-615.

Le Deuff R.M . \& Renault, T. (1993). Lymphocystis outbreaks in farmed seabream, Sparus aurata, first report on French Mediterranean coast. Bulletin of European Association of Fish Pathology, 13, 130-133.

Mao, J., Tham, T.N., Gentry, G.A., Aubertin, A., and Chinchar, V.G. (1996). Cloning, sequence analysis, and expression of the major capsid protein of the iridovirus frog virus 3. Virology, 216, 431-436.

Ministry of Marine Affairs and Fisheries. (2019). Aquatic animal welfare management. Permen KP draft 02 Agustus 2019. Unpublished.

Pirarat, N., Pratakpiriya, W., Jongnimitpaiboon, K., Sajjawiriyakul, K., Rodkhum, C., \& Chansue, N. (2011). Lymphocystis disease in cultured false clown anemone fish (Amphiprion ocellaris). Aquaculture, 315, 414-416.

Qin, W.Q., Gin, K.Y., Lee, L.Y., Gedaria, A.I., \& Zhang, S. (2006). Development of cytometry based method for rapid and sensitive detection of a novel marine fish iridovirus in cell culture. Journal of Virology M ethods, 125, 49-54.

Shang, X.Z. \& Zhan, W.B. (2006). Histopathological studies on the target organs of lymphocystis disease virus of fish. Periodical Ocean University of China, 36, 749-753.

Valverde, E.J., Borrego, J.J., Sarasquete, M.C., OrtizDelgado, J.B., \& Castro, D. (2017). Target organs for lymphocystis disease virus replication in gilthead seabream (Sparus aurata). Veterinary Research, 48, 21; DOI: 10.1186/s13567-017-0428-3.

Zhang, Q.Y., Xiao, F., Xie, J., Li, Z.Q., \& Gui, J.F. (2004). Complete genome sequence of lymphocystis disease virus isolated from China. J. Virol., 78, 6982-6994. 